\title{
The decline of calendar seasonality in the Australian stock exchange, 1958-2005
}

\author{
Andrew C. Worthington
}

\begin{abstract}
This paper examines calendar effects in Australian daily stock returns from 6 January 1958 to 30 December 2005. Three calendar effects - day-of-the-week, turn-of-themonth and month-of-the-year - are examined using parametric tests and a regression-based approach. The results indicate that the Australian market is characterised by seasonality of all three forms, with Tuesday, September and the second trading day of the month the most significant. However, there is also evidence of parameter instability and structural breaks in these relationships, with day-of-the-week effects becoming less important in the post-1987 crash period.
\end{abstract}

Keywords Calendar effects · Market anomalies · Market efficiency

JEL Classification $\mathrm{C} 12 \cdot \mathrm{C} 22 \cdot \mathrm{G} 14$

\section{Introduction}

A consistent theme in the market efficiency literature has concerned the presence of calendar anomalies or seasonality in stock returns. If, and as hypothesised, readily identifiable seasonal patterns occur there is the possibility of abnormal returns through market timing strategies. Within this burgeoning literature, well-known calendar anomalies concerning security returns include: a weekend effect, where stocks exhibit lower returns between Friday and Monday

The author would like to thank two anonymous reviewers, conference attendees at the 2007 British Accounting Association Conference, London, $14^{\text {th }}$ Global Finance Conference, Melbourne, and $12^{\text {th }}$ FINSIA-Melbourne Centre for Financial Studies Banking and Finance Conference, Melbourne, and seminar participants at the University of Wollongong for helpful comments on an earlier version of this paper.

Department of Accounting, Finance and Economics, Griffith University, Nathan QLD 4111, Australia e-mail: a.worthington@griffith.edu.au 
closing (Agrawal and Ikenberry 1994; Wang and Erickson 1997 Zainudin and Coutts 1997); a day-of-the-week effect, where returns on some trading days are higher than others (Chang et al. 1993; Kamara 1997; Chang et al. 1998); a January effect, where returns are much higher than any other month (Haugen and Jorion 1996; Tonchev and Kim 2004; Rosenberg 2004); a holiday effect, where returns are higher on trading days prior to public holidays (Kim and Park 1994; Chan et al. 1996; Brockman and Michayluk 1998; Vergin and McGinnis 1999; Chong et al. 2005; McGuinness 2005); and a turn-of-the month effect, where returns are higher during the first few trading days of each month (Cadsby and Ratner 1992; Tonchev and Kim 2004).

A number of hypotheses have been put forward to explain the presence of such seasonality, especially concerning its three principal forms: (i) the day-of-the-week effect, (ii) the turn-ofthe-month effect, and (iii) the month-of-the-year effect. First, the day-of-the-week effect is potentially explained by an information release hypothesis, whereby firms delay the release of negative information until late in the week, a settlement regime hypothesis, associated with differences in the timing of transactions and settlement, and an information processing hypothesis linked with the asymmetry in information costs across small and large investors [see, for example, Keim and Stambaugh (1984), Junkus (1986), Thaler (1987), Rystrom and Bensen (1989), Abraham and Ikenberry (1994), Arsad and Coutts (1997) and Keef and Roush (2005)]. The most commonly reported anomaly in this respect is significantly lower (if not negative) Monday returns. This appears to hold even with allowance for changes in settlement regimes over time, as in Keef and McGuiness' (2001) analysis of the New Zealand stock market. However, the Monday effect is not consistent in all contexts. For instance, Jaffe and Westerfield (1985), Finn et al. (1991), Easton and Faff (1994), Agrawal and Tandon (1994) and Davidson and Faff (1999) find a significantly negative Tuesday effect in Australian stock returns, and Jaffe and Westerfield (1985) propose a linkage between Tuesdays in the AsiaPacific and the (negative) Monday effect in the US.

Second, the turn-of-the-month effect is where returns are substantially positive during the first few days in each trading month [see, for instance, Jacons and Levi (1988), Lakonishok and Smidt (1988), Khaksari and Bubnys (1992), Mills et al. (2000) and Holden et al. (2005)]. Three explanations have been put forward: a portfolio rebalancing hypothesis, where investors reinvest accumulated dividends at the end of each month; a month-end cash flow hypothesis linked with the transfer of income from salaries and other income into long-term 
financial assets; and a company announcement hypothesis reflecting the preference of companies to delay bad news until late in the reporting period. Finally, the month-of-the-year effect is almost always construed in terms of higher January returns [see, for example, Gultekin and Gultekin (1987), Ariel (1987), Arsad and Coutts (1997), Mehdian and Perry (2002) and Al-Saad and Moosa (2005)]. Once again, three possible explanations have been put forward. These include: the tax-loss selling hypothesis whereby losses on portfolios are fixed for tax purposes at the end of the (US) financial year; a yearly investor cash flow hypothesis, where individual investors (and the market) benefit from year-end bonuses, holiday pay and gifts; and a company announcement hypothesis whereby January is characterised by the abnormally large release of (positive) firm information.

The purpose of this paper is to add to this intriguing body of work an analysis of calendar effects in the Australian equity market. Although the Australian market has been partially addressed in a number of studies a comprehensive analysis remains, as yet, undone. In particular, it is rare to see a variety of calendar effects analysed in a single study, and as a result their relative strength is unknown. At the same time, it is sometimes assumed that calendar effects are stable over time, and not subject to the usual changes in market efficiency associated with the development and internationalisation found in contemporary equity markets. This is now subject to some debate. For example, in their analysis of the US, UK and Hong Kong markets, Chong et al. (2005) concluded that the typically positive pre-holiday effect reversed and became negative from 1991 to 1997, with its subsequent elimination between 1997 and 2003. An additional objective of this paper is then to assess whether these calendar effects have declined over time.

The remainder of the paper is organised as follows. Section 2 explains the empirical methodology and data employed in the study and provides a brief descriptive analysis. The empirical findings are presented and analysed in Section 3. The paper ends with a brief conclusion in the final section.

\section{Data and methodology}

The data employed in the study are closing prices from the Australian Stock Exchange (ASX) over the period 6 January 1958 to 30 December 2005 encompassing 12,067 trading days. The capitalization-weighted All Ordinaries Price Index is used. This index includes the top ASXlisted stocks by capitalization, covering about 92 percent of domestic companies by market 
value. To be included in the index stocks must have an aggregate market value of at least 0.02 percent of all domestic equities, and maintain an average turnover in excess of 0.5 percent of quoted shares each month. The long-term market index series is obtained from Global Financial Data (2006). A series of daily market returns are calculated where $R_{t}=100 \ln \left(P_{t} / P_{t-1}\right)$ where $P_{t}$ is the index level at the end of day $t$.

Two approaches are used to test the seasonality hypotheses. The first involves a descriptive analysis of the mean returns and tests of equality of means using parametric analysis. Parametric testing is appropriate because with very large samples like this the sample means will follow the normal distribution, even if the underlying variable is not normally distributed in the population. Moreover, parametric tests have more statistical power than their nonparametric counterparts. The second is a regression-based approach. First, the following model is specified for the day-of-the-week effect:

$$
R_{t}=\alpha_{0}+\sum_{i=1}^{4} \alpha_{i} W_{i t}+\varepsilon_{t}
$$

where $W_{i}$ is a dummy variable taking a value of one for day $i$ and zero otherwise (where $i=$ $1,2,3,4$ ) (the reference category is Wednesday), $\alpha$ are parameters to be estimated, $\varepsilon$ is the error term and all other variables are as previously defined. Second, the turn-of-the-month effect is described by the following:

$$
R_{t}=\beta_{0}+\sum_{j=1}^{3} \beta_{j} D_{j t}+\phi_{t}
$$

where $D_{j}$ is a dummy variable taking a value of one for trading day $j$ and zero otherwise (where $j=1,2,3$ ) (the reference category is all other trading days of the month following the third trading day), $\beta$ are parameters to be estimated, $\phi$ is the error term and all other variables are as previously defined. Third, the month-of-the-year effect is specified as:

$$
R_{t}=\chi_{0}+\sum_{k=1}^{11} \chi_{k} M_{k t}+\varphi_{t}
$$

where $M_{k}$ is a dummy variable taking a value of one for month $k$ and zero otherwise (where $k$ $=1,2 \ldots 11$ ) (the reference category is July), $\chi$ are parameters to be estimated, $\varphi$ is the error term and all other variables are as previously defined. Finally, a calendar effect model is specified:

$$
R_{t}=\delta_{0}+\sum_{i=1}^{4} \alpha_{i} W_{i t}+\sum_{j=1}^{3} \beta_{j} D_{j t}+\sum_{k=1}^{11} \chi_{k} M_{k t}+\gamma_{t}
$$


where all variables and parameters are as previously described, $\delta$ is a constant and $\gamma$ is the error term. An Augmented Dickey-Fuller test (statistic $=-55.4424, p$-value $=0.0000$ ) and a Phillips-Peron test (with allowance for autocorrelation) (statistic $=-93.1849, p$-value $=$ 0.0000) reject the null hypothesises of a unit root and we conclude that the return series is stationary and suitable for regression-based analysis.

\section{Empirical findings}

Table 1 presents the summary of descriptive statistics for the daily returns. These are categorised according to the hypothesised day-of-the-week, turn-of-the-month and month-ofthe-year effects. In terms of the day-of-the-week, mean returns are highest on Thursday (0.0811) and lowest on Tuesdays (-0.0386). The volatility of returns (as measured by standard deviation) is also highest on Tuesdays (0.9230) and lowest on Fridays (0.7354). For the turnof-the-month, the returns on the first, second and third trading days are higher and less volatile than other trading days in the month. Finally, in terms of calendar months, returns are lowest in September (-0.0402) and highest in December (0.1287) and least variable in July (0.6954) and more variable in October (1.3030).

\section{$<$ TABLE 1 HERE $>$}

By and large, the distributional properties of the returns series in all categories appear nonnormal. Given that the sampling distribution of skewness is normal with mean 0 and standard deviation of $\sqrt{6 / T}$ where $\mathrm{T}$ is the sample size, then returns on Mondays, Tuesdays, Thursdays and Fridays (Wednesdays) are significantly negatively (positively) skewed indicating the greater likelihood of observations lying below (above) the mean. The turn-ofthe-month days are also significantly skewed, with the first and second being positively skewed and the third negatively skewed. The months are also primarily negatively skewed, with January, July and November being positively skewed. The kurtosis or degree of excess across all return categories is also large, indicating leptokurtic distributions with many extreme observations. Given the sampling distribution of kurtosis is normal with mean 0 and standard deviation of $\sqrt{24 / T}$ where $\mathrm{T}$ is the sample size, then all estimates are once again statistically significant at any conventional level. Finally, the Jarque-Bera statistics reject the null hypotheses of normality at the .01 level for all returns by category. 


\subsection{Parametric tests of mean return differences}

At first impression, there appears to be strong evidence of calendar effect in the Australian stock market. Consider the days-of-the-week. Tests of the null hypotheses of equal variances are rejected for Monday and Friday (compared to returns on other days). The tests in Table 1 comparing these mean returns also indicate that the differences in means are statistically significant at the .05 level or lower with the exception of Wednesday. With the turn-of-themonth days, in no instance is the null hypothesis of equal variances rejected and only in the case of the second trading day of the month is the null hypothesis of equal means rejected. Finally, return variances are significantly different in February, May, June, July, October, November and December, though significant differences in means at the .10 level or lower are only found in January, February, April, September and December.

\subsection{Regression-based analysis of seasonality}

The estimated coefficients and standard errors of the parameters detailed in Equations (1) to (4) are presented in Table 2. Table 2 also includes the $\mathrm{R}^{2}$ and adjusted $\mathrm{R}^{2}$, an F-test of the null hypothesis that all slope coefficients are jointly zero and Breusch-Godfrey and White's statistics. Breusch-Godfrey Lagrange multiplier and White’s heteroskedasticity tests are used to test for higher-order serial correlation and heteroskedasticity in the least squares residuals, respectively. To start with, the null hypothesis of no serial correlation is rejected for all four models and we may conclude the presence of higher-order serial correlation in the residuals. Then the null hypothesis of no heteroskedasticity in the least squares residuals fails to be rejected for the model based on Equations (1) and (2) and we conclude the presence of heteroskedasticity in the least squares residuals. Accordingly, all standard errors in Table 2 incorporate corrections for heteroskedasticity and autocorrelation following Newey-West.

\section{$<$ TABLE 2 HERE $>$}

Consider the day-of-the-week model. The estimated coefficient for Tuesday is significantly negative while those for Thursday and Friday are significantly positive. Clearly, the Australian market is characterised by the Tuesday effect observed in earlier studies. With the turn-of-the-month effect, only the estimated coefficient for the second trading is significant. Conventionally, the first trading day of the month is expected to have the higher returns under the turn-of-the-month effect. One possibility is that as the negative Tuesday effect in Australia potentially represents a delayed Monday effect in the US market, the positive second effect 
may correspond to the delayed transmission of the (positive) turn-of-the-month effect from the US. With the month-of-the-year model, the coefficients for February and September are both significantly negative. The combined model represented by Equation (4) includes the day-of-the-week, turn-of-the-month and month-of-the-year variables with the results being consistent with the earlier findings. In all four models, the null hypothesis of joint insignificance is rejected at the .01 level. The signs on the estimated coefficients in these four models appear to offer support for the posited calendar effects.

\section{$<$ TABLE 3 HERE $>$}

In order to examine the long-run stability of the parameters in this model, cumulative sum of squares tests are run and the results plotted (not shown). All other things being equal, movement outside the 5 percent critical lines is suggestive of parameter instability. Using this approach, some evidence of parameter instability is found, with a significant structural break corresponding to October 1987. Accordingly, a Chow breakpoint test (F-statistic $=2.3111, p$ value $=0.0046$ ) is conducted with a break on 20 October 1987 (Australia's largest one-day market fall). Since the null hypothesis of parameter stability is rejected, the refined model is re-estimated for two non-overlapping sub-samples: 6 January 1958 to 19 October 1987 and 20 October 1987 to 30 December 2005. The results for these models are presented in Table 3.

In general, the significance, magnitude and sign of the coefficients in the earlier period (Table 3) are comparable with the entire sample period (Table 2). However, in the post-1987 crash period, only the coefficients for the second and September are still significant and the null hypothesis of the joint insignificance of the slope coefficients fails to be rejected. Interestingly, calendar effects in the pre-1987 period and overall are dominated by day-of-theweek effects (Tuesday, Thursday and Friday). However, in the post-1987 period, there is only the influence of a single month-of-the-year effect (September) and a single day-of-the-month effect (Second). In order to gain further insights into the stability of individual parameters, plots of selected coefficients in the equation for all feasible recursive estimations are estimated (not shown). As a rule, if a coefficient displays significant variation as more data is added to the estimating equation, it is a strong indication of instability. These plots also indicate instability and a decline in the calendar effect coefficients over time. 


\section{Conclusion}

This study examines the presence of calendar effects or seasonality in Australian market returns over the period 1958 to 2005. Three manifestations of calendar effects are examined: namely, the day-of-the-week effect, the turn-of-the-month effect and the month-of-the-year effect. Many of the results are consistent with the established literature in Australia and elsewhere: a negative Tuesday effect and positive Thursday and Friday effects; a negative February and September effect; and a positive market impact on the second trading day of the month. The three most substantive Australian calendar effects over the entire sample period are the negative Tuesday effect, the negative September effect and the positive second of the month effect. There is no evidence, at least in the Australian market, of the January, Monday and first trading day of the month effects sometimes observed in the US market. However, there is some suggestion that the significant Tuesday and second trading day of the month effects may correspond to the lagged influence of the US market.

Importantly, the estimated parameters in the equations are not structurally stable over the full sample period and there is a statistically significant intertemporal break at the time of the 1987 stock market crash. The calendar effects are then re-examined in the pre-crash period and post-crash periods. In the pre-crash period, the Australian market is strongly characterised by seasonal factors. But in the post-crash period, the market appears to display less and less complex seasonality. Since seasonal anomalies represent unexploited profit opportunities and violate market efficiency, the disappearance of seasonality may imply that the Australian stock market has gradually become more (weak form) efficient in the post-crash period. A number of contributory factors are possible, including the growth in derivative markets, the increasing internationalisation and liberalisation of the domestic capital market, increased trading by institutional rather than individual investors and the dramatic fall in transaction costs, especially those relating to brokerage, taxation and information procurement.

It is also possible that factors not conventionally assigned to improvements in efficiency have had an affect. For example, the substantial changes in settlement regimes over time in Australia may have had a role to play, especially with the day-of-the-week effects, and a useful extension to this work would follow the approach of Keef and McGuiness (2001) and reflect this more fully. Likewise, Connolly (1989) finds that large time series datasets may bias the findings of classical test statistics and concludes that large sample sizes quite often favour the null hypothesis of equal returns across days of the week and bias hypothesis tests 
in the direction of an anomaly for the weekend effect. Sensitivity analysis in the spirit of Connolly (1989) would then also be useful to place work on calendar effects in the Australian market on a more secure statistical footing.

Finally, there are very many interactions possible between the three calendar effects in this study and yet other calendar anomalies that we could not cover (for reasons of brevity and complexity). For instance, a broader test of the 'turn-of-the-month' effect could incorporate the week-of-the-month effects considered by Ariel (1988) in the US. Similarly, Wang et al. (1997) found that the Monday effect might help in explaining subdued returns in the US in the final and penultimate weeks of each calendar month. It is then possible that week-of-themonth effects are much stronger than any day-of-the-week effect. Lastly, the higher Thursday and Friday returns found in some parts of this analysis may be due, in part, to pre-holiday effects. As elsewhere, a disproportionate (but small) number of holidays in Australia take place before Fridays and/or Mondays. These all provide possible research extensions.

\section{References}

Abraham, A., Ikenberry, D.L.: The individual investor and the weekend effect. J Financ Quant Analy 29, 263277 (1994).

Agrawal, A., Tandon, K.: Anomalies of illusions? Evidence from stock markets in eighteen countries. J Int Money Financ 13, 83-106 (1994)

Agrawal, A., Ikenberry, D.L.: The individual investor and the weekend effect. J Financ Quant Analy 29, 263277 (1994)

Al-Saad, K., Moosa, I.A.: Seasonality in stock returns: Evidence from an emerging market. App Financ Econ 15, 63-71 (2005)

Ariel, R.A.: A monthly effect in stock returns. J Financ Econ 18, 161-174 (1987)

Ariel, R.A.: Evidence on intra-month seasonality in stock returns, in Stock market anomalies (Ed.), E. Dimson, Cambridge University Press, 109-119 (1988)

Arsad, Z., Coutts, J.A.: Security price anomalies in the London International Stock Exchange: A 60 year perspective. App Financ Econ 7, 455-464 (1997)

Brockman, P., Michayluk, D.: The persistent holiday effect: Additional evidence. App Econ Lett 5, 205-09 (1998)

Cadsby, C.B., Ratner, M.: Turn-of-month and pre-holiday effects on stock returns: Some international evidence. J Bank Financ 16, 497-509 (1992)

Chan, M.W.L., Khanthavit, A., Hugh, T.: Seasonality and cultural influences on four Asian stock markets. Asia Pac J Manag 13, 1-24 (1996)

Chang, E.C., Pinegar, J.M., Ravichandra, R.: International evidence on the robustness of the day-of-the-week effect. J Financ Quant Analy 28, 497-513 (1993)

Chang, E.C., Pinegar, J.M., Ravichandran, R.: U.S. day-of-the-week effects and asymmetric responses to macroeconomic news. J Bank Financ 22, 513-534 (1998)

Chong, R., Hudson, R., Keasey, K., Littler, K.: Pre-holiday effects: International evidence on the decline and reversal of a stock market anomaly. J Int Money Financ 24, 1226-1236 (2005)

Connolly, R.A., An examination of the robustness of the weekend effect. J Financ Quant Analy 24, 133-169 (1989)

Davidson, S., Faff, R.: Some additional Australian evidence on the day of the week effect. App Econ Lett 6, 247-249 (1999)

Easton, S.A., Faff, R.W.: An investigation of the robustness of the day-of-the-week effect in Australia. App Financ Econ 4, 99-110 (1994) 
Finn, F.J., Lynch, A., Moore, S.: Intra-week regularities in security returns: Further Australian evidence. Aust J Manag 16, 129-144 (1991)

Global Financial Data: (2006). http://www.globfindata.com, Accessed February 2006.

Gultekin, M., Gultekin, N.B.: Stock market seasonality: International evidence. J Financ Econ 12, 469-481 (1983)

Haugen, R.A., Jorion, P.: The January effect: Still there after all these years. Financ Analy J 52, 27-31 (1996)

Holden, K., Thompson, J., Ruangrit, Y.: The Asian crisis and calendar effects on stock returns in Thailand. Eur J Operat Res 163, 242-252 (2005)

Jacons, B.I., Levy, K.N.: Calendar anomalies: Abnormal returns are calendar turning points, Financ Analy J 44, 28-39 (1988)

Jaffe, J.F., Westerfield, R.: The weekend effect in common stock returns: The international evidence. J Financ 40, 433-454 (1985)

Junkus, J.C.: Weekend and day of the week effects in returns on stock index futures. J Fut Mark 6, 397-407 (1986)

Kamara, A.: New evidence on the Monday seasonal in stock returns. J Bus 70, 63-84 (1997)

Keef, S.P., McGuinness, P.B.: Changes in settlement regime and the modulation of day-of-the-week effects in stock returns. App Financ Econ 11, 361-372 (2001)

Keef, S.P., Roush, M.L.: Day-of-the-week effects in the pre-holiday returns of the Standard and Poor's 500 stock index. App Financ Econ 15, 107-119 (2005)

Keim, D.B., Stambaugh, R.F.: A further investigation of the weekend effect in stock returns. J Financ 39, 819835 (1984)

Khaksari, S., Bubnys, E.L.: Risk-adjusted day-of-the-week, day-of-the-month and month-of-the-year effects on stock indexes and stock index futures. Financ Rev 27, 531-552 (1992)

Kim, C., Park, J.: Holiday effects and stock returns: Further evidence. J Financ Quant Analy 29, 145-157 (1994)

Lakonishok, J., Smidt, S. Are seasonal anomalies real? A ninety-year perspective. Rev Financ Stud 1, 403-425 (1988)

McGuinness, P.B.: A re-examination of the holiday effect in stock returns: The case of Hong Kong. App Financ Econ 15, 1107-1123 (2005)

Mehdian, S., Perry, M.J.: Anomalies in US equity markets: A re-examination of the January effect. App Financ Econ 12, 141-145 (2002)

Mills, T.C. Siriopoulos,, C. Markellos, R.N., Harizanis, D.: Seasonality in the Athens stock market. App Financ Econ 10, 137-142 (2000)

Rosenberg, M.: The monthly effect in stock returns and conditional heteroskedasticity. Amer Econ 48, 67-73 (2004)

Rystrom, D.S., Benson, E.D.: Investor psychology and the day-of-the-week effect. Financ Analy J 45, 75-78 (1989)

Thaler, R.: Seasonal movements in security prices II: Weekend, holiday, turn of the month and intraday effects. J Econ Persp 1, 169-177 (1987)

Tonchev, D., Kim, T.H.: Calendar effects in Eastern European financial markets: Evidence from the Czech Republic, Slovakia and Slovenia. App Financ Econ 14, 1035-1043 (2004)

Vergin, R.C., McGinnis, J.: Revisiting the holiday effect: Is it on holiday? App Financ Econ 9, 477-482 (1999)

Wang, K., Li, Y., Erickson, J.: A new look at the Monday effect. J Financ 52, 2171-2186 (1997)

Zainudin, A., Coutts, J.A.: Security price anomalies in the London International Stock Exchange: A 60 year perspective. App Financ Econ 7, 455-464 (1997) 
Table 1 Descriptive analysis of daily returns

\begin{tabular}{|c|c|c|c|c|c|c|c|c|c|c|c|c|c|c|}
\hline \multirow[t]{2}{*}{ Variable } & \multicolumn{7}{|c|}{ Variable category } & \multicolumn{3}{|c|}{ Reference category } & \multicolumn{2}{|c|}{$\begin{array}{l}\text { Tests of equality of } \\
\text { variances }\end{array}$} & \multicolumn{2}{|c|}{$\begin{array}{c}\text { Tests of equality of } \\
\text { means }\end{array}$} \\
\hline & Number & Mean & $\begin{array}{l}\text { Standard } \\
\text { deviation }\end{array}$ & Skewness & Kurtosis & $\begin{array}{c}\mathrm{JB} \\
\text { statistic }\end{array}$ & $\begin{array}{c}\text { JB } \\
p \text {-value }\end{array}$ & Number & Mean & $\begin{array}{l}\text { Standard } \\
\text { deviation }\end{array}$ & F-statistic & $p$-value & $t$-statistic & $p$-value \\
\hline Monday & 2258 & 0.0005 & 0.9069 & -0.5911 & 14.9106 & $1.3 \mathrm{E}+04$ & 0.0000 & 9810 & 0.0405 & 0.8116 & 20.4010 & 0.0000 & 1.9236 & 0.0545 \\
\hline Tuesday & 2458 & -0.0386 & 0.9230 & -8.2871 & 223.7458 & $5.0 \mathrm{E}+06$ & 0.0000 & 9610 & 0.0513 & 0.8039 & 0.2896 & 0.5905 & 4.7926 & 0.0000 \\
\hline Wednesday & 2470 & 0.0398 & 0.8081 & 0.4218 & 10.7877 & $6.3 \mathrm{E}+03$ & 0.0000 & 9598 & 0.0312 & 0.8360 & 0.5772 & 0.4474 & -0.4610 & 0.6448 \\
\hline Thursday & 2467 & 0.0811 & 0.7604 & -0.3131 & 9.9222 & $5.0 \mathrm{E}+03$ & 0.0000 & 9601 & 0.0206 & 0.8470 & 2.0094 & 0.1564 & -3.2273 & 0.0013 \\
\hline Friday & 2414 & 0.0800 & 0.7354 & -0.5551 & 10.9265 & $6.4 \mathrm{E}+03$ & 0.0000 & 9654 & 0.0212 & 0.8521 & 12.5719 & 0.0004 & -3.4006 & 0.0007 \\
\hline First trading day & 529 & 0.0495 & 0.8074 & 0.3427 & 8.7646 & $7.4 \mathrm{E}+02$ & 0.0000 & 11538 & 0.0322 & 0.8314 & 0.0100 & 0.9190 & -0.4670 & 0.6410 \\
\hline Second trading day & 529 & 0.1322 & 0.7089 & 0.3786 & 4.2188 & $4.5 \mathrm{E}+01$ & 0.0000 & 11538 & 0.0284 & 0.8352 & 1.5200 & 0.2180 & -2.8110 & 0.0050 \\
\hline Third trading day & 529 & 0.0635 & 0.7917 & -0.8008 & 9.3724 & $9.5 \mathrm{E}+02$ & 0.0000 & 11538 & 0.0315 & 0.8320 & 0.0240 & 0.8760 & -0.8650 & 0.3870 \\
\hline January & 965 & 0.1015 & 0.7742 & 0.5985 & 7.8368 & $1.0 \mathrm{E}+03$ & 0.0000 & 11103 & 0.0270 & 0.8348 & 0.0390 & 0.8434 & -2.6722 & 0.0075 \\
\hline February & 962 & -0.0195 & 0.8099 & -0.3183 & 4.9638 & $1.7 \mathrm{E}+02$ & 0.0000 & 11106 & 0.0375 & 0.8320 & 3.0314 & 0.0817 & 2.0901 & 0.0368 \\
\hline March & 1038 & 0.0106 & 0.7529 & -0.0438 & 5.6609 & $3.1 \mathrm{E}+02$ & 0.0000 & 11030 & 0.0351 & 0.8373 & 0.2948 & 0.5872 & 0.9086 & 0.3636 \\
\hline April & 915 & 0.1002 & 0.7666 & -0.4023 & 8.9872 & $1.4 \mathrm{E}+03$ & 0.0000 & 11153 & 0.0275 & 0.8351 & 0.3237 & 0.5694 & -2.5494 & 0.0108 \\
\hline May & 1062 & 0.0348 & 0.7188 & -0.0302 & 5.3423 & $2.4 \mathrm{E}+02$ & 0.0000 & 11006 & 0.0328 & 0.8403 & 3.1802 & 0.0746 & -0.0871 & 0.9306 \\
\hline June & 982 & 0.0076 & 0.7171 & -0.4423 & 10.1574 & $2.1 \mathrm{E}+03$ & 0.0000 & 11086 & 0.0352 & 0.8396 & 7.6777 & 0.0056 & 1.1388 & 0.2550 \\
\hline July & 1063 & 0.0657 & 0.6954 & 0.0717 & 5.4641 & $2.7 \mathrm{E}+02$ & 0.0000 & 11005 & 0.0298 & 0.8422 & 6.7212 & 0.0095 & -1.5755 & 0.1154 \\
\hline August & 1040 & 0.0256 & 0.7346 & -0.3418 & 6.4766 & $5.4 \mathrm{E}+02$ & 0.0000 & 11028 & 0.0337 & 0.8388 & 2.3241 & 0.1274 & 0.3014 & 0.7631 \\
\hline September & 1029 & -0.0402 & 0.8305 & -0.5825 & 16.4350 & $7.8 \mathrm{E}+03$ & 0.0000 & 11039 & 0.0398 & 0.8300 & 0.0014 & 0.9703 & 2.9584 & 0.0031 \\
\hline October & 1040 & -0.0055 & 1.3030 & -7.4288 & 138.3602 & $8.0 \mathrm{E}+05$ & 0.0000 & 11028 & 0.0366 & 0.7709 & 49.0219 & 0.0000 & 1.0262 & 0.3050 \\
\hline November & 1027 & 0.0007 & 0.9328 & 0.5708 & 13.6128 & $4.9 \mathrm{E}+03$ & 0.0000 & 11041 & 0.0360 & 0.8201 & 6.8415 & 0.0089 & 1.1690 & 0.2427 \\
\hline December & 944 & 0.1287 & 0.7005 & -0.0390 & 5.3304 & $2.1 \mathrm{E}+02$ & 0.0000 & 11124 & 0.0248 & 0.8400 & 6.3817 & 0.0115 & -4.3012 & 0.0000 \\
\hline
\end{tabular}

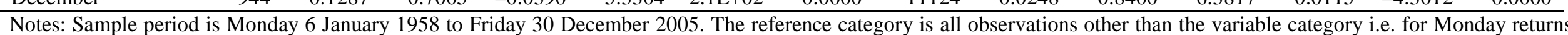

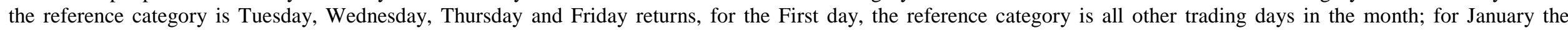
reference category is all other months; number - number of observations in each category.

The test for equality of variances is $L=(W-2) \sum_{k=1}^{2} W_{k}\left(\bar{Z}_{k i}-\bar{Z}\right)^{2} / \sum_{k=1}^{2} \sum_{i=1}^{n k} w_{k i}\left(\bar{Z}_{k i}-\bar{Z}_{k}\right)^{2}$ where $Z_{k i}=\left|X_{k i}-\bar{X}_{k}\right|>\bar{Z}_{k}=\sum_{i=1}^{n_{k}} w_{k i} Z_{k i} / W_{k}$ and $\bar{Z}=\sum_{k=1}^{2} w_{k} \bar{Z}_{k} / W_{1}+W_{2}$.

The test for equality of means is $t=D / S_{D}, d f^{\prime}=\frac{1}{Z_{1}+Z_{2}}$ (unequal variances) and $t^{\prime}=D / S_{D}^{\prime}, d f=W_{1}+W_{2}-2$ (equal variances) where $Z_{k}=\left(\frac{S_{k}^{2} / W_{k}}{S_{1}^{2} / W_{1}+S_{2}^{2} / W_{2}}\right)^{2} /\left(W_{k}-1\right) t=D / S_{D} d f^{\prime}=\frac{1}{Z_{1}+Z_{2}}$. 
Table 2 Estimated coefficients and standard errors of day-of-the-week, day-of-the-month, month-of-the-year and calendar effect models

\begin{tabular}{|c|c|c|c|c|c|c|c|c|}
\hline & \multicolumn{2}{|c|}{ Day-of-the-week effect } & \multicolumn{2}{|c|}{ Turn-of-the-month effect } & \multicolumn{2}{|c|}{ Month-of-the-year effect } & \multicolumn{2}{|c|}{ Calendar effect } \\
\hline & Coefficient & Std. error & Coefficient & Std. error & Coefficient & Std. error & Coefficient & Std. error \\
\hline Constant & $0.0398^{* *}$ & 0.0164 & $0.0256^{* *}$ & 0.0102 & $0.0657^{* *}$ & 0.0291 & $0.0613^{*}$ & 0.0330 \\
\hline Monday & -0.0393 & 0.0252 & - & - & - & - & -0.0354 & 0.0254 \\
\hline Tuesday & $-0.0784^{* * *}$ & 0.0243 & - & - & - & - & $-0.0819^{* * *}$ & 0.0246 \\
\hline Wednesday & - & - & - & - & - & - & - & - \\
\hline Thursday & $0.0412^{* *}$ & 0.0209 & - & - & - & - & $0.0446^{* *}$ & 0.0209 \\
\hline Friday & $0.0402^{*}$ & 0.0223 & - & - & - & - & $0.0449^{* *}$ & 0.0223 \\
\hline First & - & - & 0.0239 & 0.0366 & - & - & 0.0437 & 0.0371 \\
\hline Second & - & - & $0.1066^{* * *}$ & 0.0323 & - & - & $0.1332^{* * *}$ & 0.0326 \\
\hline Third & - & - & 0.0379 & 0.0342 & - & - & 0.0405 & 0.0341 \\
\hline January & - & - & - & - & 0.0358 & 0.0446 & 0.0441 & 0.0445 \\
\hline February & - & - & - & - & $-0.0852^{* *}$ & 0.0405 & $-0.0861^{* *}$ & 0.0403 \\
\hline March & - & - & - & - & -0.0551 & 0.0399 & -0.0548 & 0.0398 \\
\hline April & - & - & - & - & 0.0345 & 0.0431 & 0.0335 & 0.0430 \\
\hline May & - & - & - & - & -0.0309 & 0.0419 & -0.0308 & 0.0418 \\
\hline June & - & - & - & - & -0.0581 & 0.0382 & -0.0601 & 0.0380 \\
\hline July & - & - & - & - & - & - & - & - \\
\hline August & - & - & - & - & -0.0402 & 0.0378 & -0.0408 & 0.0375 \\
\hline September & - & - & - & - & $-0.1060^{* *}$ & 0.0412 & $-0.1061^{* * *}$ & 0.0411 \\
\hline October & - & - & - & - & -0.0713 & 0.0589 & -0.0721 & 0.0588 \\
\hline November & - & - & - & - & -0.0650 & 0.0419 & -0.0651 & 0.0417 \\
\hline December & - & - & - & - & 0.0630 & 0.0410 & 0.0604 & 0.0411 \\
\hline $\mathrm{R}^{2}$ & 0.0031 & - & 0.0008 & - & 0.0037 & - & 0.0080 & - \\
\hline Adjusted $\mathrm{R}^{2}$ & 0.0028 & - & 0.0005 & - & 0.0028 & - & 0.0065 & - \\
\hline F-statistic & $9.5052^{* * *}$ & - & $3.1017^{* *}$ & - & $4.0258^{* * *}$ & - & $5.3747^{* * *}$ & - \\
\hline Breusch-Godfrey & $183.5907^{* * *}$ & - & $184.4989^{* * *}$ & - & $178.6054^{* * *}$ & - & $175.7259^{* * *}$ & - \\
\hline White & $1.3061^{*}$ & - & 0.21288 & - & $3.1858^{* * *}$ & - & $2.2903^{* * *}$ & - \\
\hline
\end{tabular}

Asterisks indicate significance at the ${ }^{*}-.10,^{* *}-.05$ and ${ }^{* * *}-.01$ levels. Sample period Monday 6 January 1958 to Friday 30 December 2005. The dummy variable reference categories are Wednesday, trading days of the month after the third day and July. F-test is of null hypothesis that all slope coefficients are zero. Breusch-Godfrey - Breusch-Godfrey serial correlation LM test for ordinary least squares regression model, White - White heteroskedasticity test for ordinary least squares regression model. All standard errors and $p$-values incorporate Newey-West corrections for heteroskedasticity and autocorrelation of unknown form. 
Table 3 Estimated coefficients and standard errors of calendar effects model

\begin{tabular}{|c|c|c|c|c|}
\hline \multirow[t]{2}{*}{ Sample } & \multicolumn{2}{|c|}{$\begin{array}{c}\text { Monday } 6 \text { January } \\
1958 \text { to Monday } 19 \\
\text { October } 1987\end{array}$} & \multicolumn{2}{|c|}{$\begin{array}{c}\text { Tuesday } 20 \text { October } \\
1987 \text { to Friday } 30 \\
\text { December } 2005\end{array}$} \\
\hline & Coefficient & Std. error & Coefficient & Std. error \\
\hline Constant & 0.0386 & 0.0429 & $0.1002^{* *}$ & 0.0494 \\
\hline Monday & -0.0266 & 0.0304 & -0.0497 & 0.0443 \\
\hline Tuesday & $-0.1007^{* * *}$ & 0.0233 & -0.0526 & 0.0518 \\
\hline Wednesday & - & - & - & - \\
\hline Thursday & $0.0849^{* * *}$ & 0.0254 & -0.0235 & 0.0365 \\
\hline Friday & $0.0943^{* * *}$ & 0.0265 & -0.0372 & 0.0390 \\
\hline First & 0.0419 & 0.0439 & 0.0483 & 0.0657 \\
\hline Second & $0.0983^{* * *}$ & 0.0378 & $0.1889^{* * *}$ & 0.0589 \\
\hline Third & $0.0800^{* *}$ & 0.0407 & -0.0293 & 0.0603 \\
\hline January & 0.0860 & 0.0614 & -0.0264 & 0.0559 \\
\hline February & $-0.0907^{*}$ & 0.0541 & -0.0788 & 0.0567 \\
\hline March & -0.0483 & 0.0527 & -0.0656 & 0.0584 \\
\hline April & 0.0430 & 0.0569 & 0.0177 & 0.0622 \\
\hline May & -0.0302 & 0.0570 & -0.0326 & 0.0563 \\
\hline June & -0.0605 & 0.0505 & -0.0592 & 0.0547 \\
\hline July & - & - & - & - \\
\hline August & -0.0178 & 0.0493 & -0.0790 & 0.0565 \\
\hline September & $-0.1025^{*}$ & 0.0549 & $-0.1118^{*}$ & 0.0581 \\
\hline October & -0.0133 & 0.0570 & -0.1656 & 0.1081 \\
\hline November & -0.0637 & 0.0562 & -0.0687 & 0.0597 \\
\hline December & 0.0803 & 0.0546 & 0.0303 & 0.0599 \\
\hline $\mathrm{R}^{2}$ & 0.0153 & - & 0.0055 & - \\
\hline Adjusted $\mathrm{R}^{2}$ & 0.0130 & - & 0.0016 & - \\
\hline F-statistic & $6.4428^{* * *}$ & - & 1.4108 & - \\
\hline jels. Sample & ifipras & correcti & $0,{ }^{* *}-.05$ & $\begin{array}{l}\text { nd }{ }^{* * *}-.0 \\
\text { st is of nul } \\
d \text { errors an } \\
\text { skedasticit }\end{array}$ \\
\hline
\end{tabular}

